\title{
Article
}

\section{Mountains of Memory, Landscapes of Loss: Scafell Pike and Great Gable as War Memorials, 1919-1924}

\author{
Westaway, Jonathan \\ Available at http://clok.uclan.ac.uk/7210/ \\ Westaway, Jonathan ORCID: 0000-0002-4479-3490 (2013) Mountains of \\ Memory, Landscapes of Loss: Scafell Pike and Great Gable as War Memorials, \\ 1919-1924. Landscapes, 14 (2). pp. 174-193. ISSN 1466-2035
}

It is advisable to refer to the publisher's version if you intend to cite from the work. http://dx.doi.org/10.1179/1466203513Z.00000000019

For more information about UCLan's research in this area go to http://www.uclan.ac.uk/researchgroups/ and search for < name of research Group>.

For information about Research generally at UCLan please go to http://www.uclan.ac.uk/research/

All outputs in CLoK are protected by Intellectual Property Rights law, including Copyright law. Copyright, IPR and Moral Rights for the works on this site are retained by the individual authors and/or other copyright owners. Terms and conditions for use of this material are defined in the policies page.

\section{CLoK}

Central Lancashire online Knowledge www.clok.uclan.ac.uk

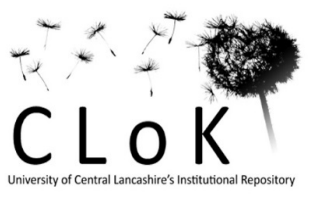




\title{
Mountains of Memory, Landscapes of Loss: Scafell Pike and Great Gable as War Memorials, 1919-24
}

\author{
JONATHAN WESTAWAY \\ University of Central Lancashire
}

\begin{abstract}
This paper examines the response of Lake District mountaineers to the Great War, particularly to the issues surrounding the establishment of a war memorial for fallen members of the Fell and Rock Climbing Club of the English Lake District (F.R.C.C.). The club's donation of land to the National Trust in 1923, with a memorial plaque on Great Gable unveiled in 1924, contributed in the minds of many mountaineers to the sacralisation of this landscape. The Lake District had already been appropriated into an imaginative sporting, athletic and exploratory territory, and one in which the geography of climbing accidents had familiarised mountaineers with the presence of death in the landscape; establishing the mountains as cenotaphs added new layers of meaning, making of the Lake District an extensive memory-laden landscape. Middle-class notions of stewardship and landscape conservation had traditionally rejected material memorialisation in the hills, but the commonality of sacrifice in the Great War reinvigorated the debate. Its donation of land to the National Trust as a war memorial reinvested significance in the link between sacrifice and the sacred, and enabled the F.R.C.C. to resolve a number of conflicts apparent in the liberal middle-classes' approach to landscape and the outdoor movement, helping the club adjust to the imminent future of widened and more democratic access.
\end{abstract}

Keywords: War memorials, Memorialisation, Lake District, Mountaineering, Sacred place

\section{Introduction}

The Fell and Rock Climbing Club of the English Lake District (F.R.C.C) was founded in the winter of 1906-1907 (Hankinson 1988, 74). Pioneered by the regional middle classes, it exemplified new approaches to the landscapes of upland Britain. Starting in the 1880s and accelerating in the 1890s, new recreational and leisure paradigms had emerged in the Lake District. Rock climbing began to differentiate itself from its Alpine mountaineering antecedents. The gentlemanly codes and social exclusivity of Alpinism began to be replaced by a new strenuousness and by wider class participation. Physical cultivation opened up new possibilities: more gymnastic forms of climbing emerged; new and steeper terrain was explored. At the same time, the hills of the Lake District became increasingly accessible by train to the urban middle class of the northern industrial cities. Regional and county pride created affective affinities between the northern cities and their upland hinterlands (Westaway 2013). Middle-class mountaineers mapped out a new cultural landscape in the Lake District in the period up to 1914, a place where they could experiment with new forms of social relations and address issues of identity. During this period, Romantic individualism dominated liberal middle-class notions of how landscape should be used, a disposition hostile to mass participation in the outdoors. But New Liberal social theorists were seeking new 
forms of collectivism based on regional identity, seeking to understand man as a natural being, situated in nature (Freeden 1976, 472). Upland landscapes came more and more to represent liminal and possibly liberal spaces, where vacation and leisure time enabled the exploration of realms outside of the economy and state regulation, a place where the antinomies of the liberal state could be addressed, and some of the tensions between individualism and collectivism, state regulation and personal liberty, access and preservation, could be overcome. Contemporaries understood the regional outdoor movement as significant and it increasingly became subjected to 'liberal governmentality' (Anderson 2011, 84).

The F.R.C.C. itself was an expression of regional pride. Founded by largely lowermiddle class residents of the Lake District, it co-opted as honorary members many eminent Alpine mountaineers living in Northern England. As a voluntary association it sought to unite different sections of the regional middle classes, occupying very different social strata, through a shared understanding of (and reverence for) the Lake District landscape, offering the possibility of escape from the fragmentation of liberalism and the restrictions of the class system. As rock climbing reached wider social groups, the F.R.C.C. addressed the criticisms of 'vulgarisation' from the Alpine mountaineering establishment by mirroring many of the institutions of middle-class clubs, showing social deference to the Alpine Club and fielding as honorary members an impressive array of Lancashire industrialists, academics and higher professionals who were also Alpine Club members. The ethos and behaviour of the F.R.C.C are indicative of a trend amongst the liberal middle classes towards self-regulation. Middleclass notions of stewardship were applied to the nascent outdoor movement, driven by concerns that the growth of mass tourism would lead to landscape desecration and to limitations being placed on individual freedoms via increased state and local government regulation of leisure.

The Great War accelerated many of these trends, contributing to the democratisation of the outdoor movement in the post-War period, and the debates within the F.R.C.C. over the nature of a memorial for members killed in the War reflected this shift in attitudes, but a consensus was slow to emerge. Some form of imaginative linking of the memory of fallen club members with the place that they loved was deemed necessary but there was criticism in the press of prospective projects reserved exclusively for the benefit of its club members. The commonality of suffering and sacrifice in the Great War had reinvigorated arguments for the restorative nature of upland landscapes and renewed arguments for access to mountains (Taylor 1997, 12, 228). Adjusting to the likelihood of a future mass-movement in the postWar outdoors, club members increasingly expressed concern about issues of landscape preservation and about regulating appropriate behaviour amongst hikers, trippers and aspirant climbers.

Two broad interrelated narratives can be detected that address these concerns: those of stewardship and sacralisation. The concept of stewardship focussed on regulating behaviour. Articles in the F.R.C.C. journal between 1914 and 1919 discussed the post-War reconstruction of the outdoor movement and how to instruct newcomers and regulate behaviour. Stewardship also required other forms of regulatory behaviour such as conservationist interventions. The immediate post-War period saw new forms of collective land ownership expand. The National Trust's special role in the Lake District, and Canon 
Rawnsley's honorary membership of the F.R.C.C., ensured a degree of convergent interest between the club and other conservationist organisations (Ranlett 1983). They formed a distinct conservationist and preservationist caucus in the Lake District that found common cause over threats such as the proposed Sty Head motor road. Alienating land from private ownership and removing it from the marketplace was part of a strategy that sought to sacralise the cultural landscape of the Lake District. Land nationalisation had long been a goal of socialist and New Liberal social theorists, but the stark dichotomies between the trenches and the countryside of the homeland in the public mind connected the sacred with the necessity of sacrifice.

\section{Mountaineering and the 'unsettling geographies' of death}

In many ways climbers were already familiar with the presence of death in the landscape. Mountaineering shared the normative codes of late Victorian masculinity exemplified by the imperial explorer and soldier hero (Mangan and Walvin 1987, 1). Narratives of conquest and subjugation had taught many climbers to view mountaineering deaths in quasi-martial terms, mountaineering literature being replete with military metaphors. A bleak sublimity pervaded Victorian mountaineering, the awareness that mountain landscapes frequently rendered pain and death immanent. As early as 1843, James Forbes recorded in his in his 'Travels through the Alps of Savoy ...'how he and his companions were affected upon discovering a body on the cliffs of Mont Collon:

'The effect on us all was electric....we turned and surveyed, with a stranger sense of sublimity than before, the desolation by which we were surrounded, and became still more sensible of our isolation from human dwellings, human help and human sympathy...We are men, and we stand in the chamber of death..' (quoted in Freedgood 2000, 103).

Accident and death rates amongst mountaineers were extremely high in the pre-War period, instigating intense speculation about the nature and value of climbing and anxiety about possible restrictive regulation. Alpine mountaineering exacted a heavy toll on the higher professions. After the death of the eminent zoologist Francis Balfour in August 1882 and a particularly bad season in the Alps, Queen Victoria famously asked if Alpine mountaineering could be banned (Fleming 2000, 298; Hall 2004). In August, 1892, the Lake District climbing pioneer Prof. John Hopkinson died in a fall on the Petit Dent de Veivisi, in the Val D’Hérens, in the Swiss Valais (Westaway 2009). The psychological impact of the accident was multiplied by its terrible circumstances, his three young children dying with him. The death of the Lake District climbing pioneer O. G. Jones on the Dent Blanche near Arolla in the Valais in 1899 had a similar seismic impact, and a popular second edition of his 1897 guidebook Rock Climbing in the English Lake District had to be published in 1900 after his death by the pioneering climbers and photographers the Abraham Brothers of Keswick (Jones 1900). As mountaineering and climbing on the hills of Britain grew in popularity, accidents and deaths became more common in the Lake District. Walker's Gully on Pillar was named after a young man who fell to his death whilst trying to rescue crag-fast scramblers on Good Friday 1883 (Hankinson 1988, 32). The primitive nature of protection 
and rope-work led to the adage 'the leader must not fall' (Hankinson 1988, 5). Falls often resulted in severe injuries (Hankinson 1988, 32), but Lakeland climbers prided themselves at the time that no one involved in a roped climbing party had died in the Lakes; with increasing participation, however, and a drive to climb harder routes, it was only a matter of time before there were fatalities.

Figures 1 and 2 hereabouts, in colour on same page please

In September 1903, Richard Broadrick of Windermere, a teacher at Fettes School, Edinburgh, and three colleagues attempted to find a route up from Lord's Rake on Scafell Pinnacle to the cairn built by Edward Hopkinson. The day was blustery and wet, one of the party slipped, and all of them fell to their deaths. It was the worst accident in British climbing until 1954 (Hankinson 1988, 72-3). Broadrick was buried in Windermere, but all the others were buried in the little churchyard of St. Olaf, Wasdale. Ramblers and walkers who had died in mountain accidents had been buried in mountain parish churchyards before (Maslen-Jones 2004, 20-5), but these three climbers were the first who had died in Wasdale to be buried there. The valley was widely regarded at the time as the birthplace of British rock climbing. The burial of climbers 'where they fell', rather than repatriating their bodies to their family or domiciliary parishes, is suggestive of increased sensibilities towards the affinities of the deceased. The psychological impact of the place and their presence in the graveyard was not lost on the actress Nancy Price, who recorded visiting the churchyard at night sometime before 1914:

'Five graves rest in the little churchyard. Beneath one of them lie the bodies of three young men who perished together on Sca Fell...I looked up at the giant who had slain them. Proudly he lifted his head to the stars, stretching himself in the calm of that peace which was once his continual portion. This was his hour. He forgot the little tracks which have been worn on his sides; forgot that his majestic purity had been polluted at the hands of men-miserable creatures who scratched his sides, and then boasted of their prowess' (Price 1937, 91-2).

Price gave voice to the increasingly secularised sensibilities around funerary practice that were more attuned to romantic and idealist values: 'They have found their resting place at the foot of the mountains their souls loved' (Price 1937, 92). Further deaths were to follow. Two climbers died in October 1908 on the North Climb on Pillar. In September 1909 Thomas Rennison attempted to lead Eagle Nest Ridge Direct on the Napes, a route so demanding that many considered it an unjustifiable risk. Rennison fell, the rope snapped and he broke his neck in the fall, dying instantly (Anon, 1909, 4; Hankinson 1988, 80). The F.R.C.C. rushed a resolution before its A.G.M. in November, 1909' (FRCCJ Committee, November 1909, 3189):

'That this club strongly condemns any member who leads or attempts to lead up any of the exceptionally severe climbs given in the list below, without having previously climbed the difficult part of 
such a course on the rope held from above, or behind a first-class cragsman who has previously led up such a course.'

There followed a list of twenty routes, including four that had been the scene of fatalities. The president of the F.R.C.C. went so far as to frame copies of part of a speech from the eminent alpinist, C. E. Matthews:

'Remember that if these fatalities continue our craft cannot fail to be discredited in all impartial eyes... do nothing that can discredit our favourite pursuit, or bring down the ridicule of the undiscerning upon the noblest pastime in the world,' (ibid, 319).

Underpinning this admonition to caution and self-regulation was an abiding fear that reckless behaviour would inevitably draw down public scrutiny and criticism. Climbers were well aware that an effective ban on climbing in the Lake District would have been simple to implement, as almost all of it took place on private land. A permissive culture of roaming beyond rights-of-way had long been tolerated in the Lake District but this could easily be rescinded. Charles Trevelyan's Access to Mountains bill was before parliament and the club was keen not to antagonise landowners, or to be associated with reckless 'trippers' and tourists (Taylor 1997, 122-3).

These accidents and deaths created spectral geographies in the Lake District, largely only detectable by those within the climbing sub-culture. The places where climbers had been injured and died lived in a collective folk memory, 'remote yet always potentially sensed as a felt variation in a field of affective materials' (McCormack 2010, 643). Mountaineering as a recreational and sporting sub-culture was predisposed to acts of memory, with a strong sense of its own history and historicising narratives. Climbing accidents, each with their own geographical locus, familiarised mountaineers with the presence of death in the landscape. . But it was felt that erecting memorials in the mountains to dead climbers would have further drawn attention, in permanent and tangible ways, to the risk involved in the sport and the potential liabilities of land owners, thus risking a withdrawal of permissive access to the fells.

\section{The debate about memorials in the mountains}

Fear of being discredited reinforced British climbers' hostility to physical memorials to the dead in the mountains, but there were other reasons. Internment in consecrated ground in a mountain churchyard was one thing, but intrusive memorials on the hills quite another. The conservationist tendencies of F.R.C.C. members made them reluctant to accept any development in the hills in terms of tourist infrastructure or memorials. The desire, so evident in the Alpine nations of Europe, to urbanise and modernise the mountains, appropriating places through hut and path building and the erection of Stein-märchen, found little parallel in Britain (Anderson 2012; Klein 2011; Hoibian 2000). Overt Christian sacralisation of mountain summits by the erection of Gipfelkreuze in Catholic Alpine regions, particularly in the Eastern Alps, was also felt to be entirely alien (Mathieu 2006). In England there was no strong association of domestic mountain summits with notions of national identity or with nationalist mythologies, in contradistinction with other nations in Europe (Mosse 1990, 114). 
The high fells of the Lake District were above all a landscape shaped by Enlightenment and pre-Romantic notions of sublimity and simplicity, largely devoid of religious or nationalist appropriations. Value was ascribed to what was assumed to be wild nature, unpeopled upland landscapes and sparse rusticity. The liberal middle-classes of the late nineteenth century also valued the un-regulated space and the opportunities for maximising individual freedoms. As such the Lake District was valued simultaneously as both a 'memorious' and a 'forgetful' landscape (Harrison 2004, 135). The individuated and idealised bourgeois-romantic 'remembering of the self' was predicated on escape from urbanism, social norms, industrialisation and modernity. The power of romantic landscapes was in part the power to achieve renewal through a forgetting of the self. The affective impact of place and memory very much rested on its intangibility, on the evanescent interplay of remembering and forgetting, something that overt materiality threatened. The haunting, revenant-like qualities of the spectral geographies of mountaineering deaths created an affective domain that registered the specificities of death in the landscape whilst acknowledging them to be signs of their own forgetting.

To be a 'first-class cragsman' as understood by contemporary mountaineers and climbers meant not only mastering the technical craft of mountaineering but also exercising judgement based on a knowledge of environmental conditions and a historical knowledge of place. Mountaineers cultivated highly developed haptic sensibilities. Muscle memory and awareness of the affordances of geology, aptitudes for geographical orientation and placememory all combined to produce a highly embodied understanding of topography. The habitus of British mountaineers and climbers was inclined to historical self-awareness but was also deeply affected by the compunctions of memory. Memory was itself a performative, embodied and 'site-located process' (Della Dora 2008, 229). To visit certain places and to climb certain routes in the Lake District was thus an affective engagement with those who had died there, a meditation on one's own mortality. It was a deeply sensed and embodied act of memory and an affiliation to place that contemporaries understood to be 'in permanent evolution, open to the dialectic of remembering and forgetting, unconscious of its successive deformations' (Nora 1989, 8). Materiality, in the form of memorials to dead climbers, threatened to collapse this affective domain and destroy the magical and intangible aspects of sub-cultural memory.

Climbers' attitudes towards formalised lieux de mémoire were first tested when the Lake District climbing pioneer John Wilson Robinson died on 20 August 1907. He had just been elected honorary chairman of the F.R.C.C. in the club's foundation year. A memorial sub-committee met in Manchester in October 1907, chaired by Charles Pilkington. Its members included 'Canon Rawnsley, Sir Wilfred Lawson, Principal Hopkinson, Prof. Procter Leeds, George B. Bryant London, W.W. Naismith, Glasgow’:

'After a number of meetings in Manchester it was agreed that a bronze tablet be appropriately inscribed and affixed to the rock at the end of the High Level route to Pillar Rock which JWR had himself pioneered. Reservations were expressed on the grounds that the memorial might create an awkward precedent, but they were overcome in view of JWR's very special standing.' (Waller 2007, 128). 
A subscription was raised and the landowner, the Earl of Lonsdale, granted permission for the memorial to be erected. All the main climbing clubs were represented when a cairn was erected on Easter Saturday 1908. There is an account of the event in the FRCC journal (Anon 1908, 126-131) (Figure 3A and B). The memorial tablet was carried up during a storm on 13 June and mounted the following Monday, 15 June.

'The party had also taken with them onto the Rock a bottle, encased in an enamelled zinc box, and containing a "Record of Memorial" written on parchment. This was to have been placed in the cairn by the tablet, but the conditions rendered this, too, impracticable. It was put there finally in August, during a meet of the club.’ (Waller 2007, 130-1).

Hostility from within the climbing community to this form of mountain memorial was overcome because of Robinson's exceptional significance as a climbing mentor and pioneer, as well as his local standing as a dalesman (Anon 1908, 126). There was a clear desire to mark the passing away of an individual whose contribution had been foundational. But there is more than a suggestion of an invented tradition in the establishment of the Robinson memorial (a cairn, a time capsule, a bronze dedicatory plaque) and of being on uncertain ground. The deep ambivalence about materialising memory in the landscape gives the Robinson memorial something of the quality of an ephemeral monument, an evanescent object 'of remembrance made in the course of rituals and destroyed or abandoned afterwards' (Harrison 2004, 135; Argenti 1999; Küchler 1999). It looks towards posterity but is also deeply ambivalent about intrusion in the landscape. Practical arguments were advanced for the cairn as a marker of the High-Level Route on Pillar. But the structure itself clearly demonstrates that 'a society's material technologies of memory are always also its technologies of forgetting' (Harrison 2004, 135). The cairn, a pile of stones, will be reduced to an unformed assemblage of stones by time and the elements. Only by remembering to place a stone back upon the cairn can the climber register the utility of the memorial, as a way-marker and as a site of memory. The discrete bronze plaque located nearby (and perhaps eventually the time capsule) serves as an aide-mémoire, discreet recognition of the mutability of memory. This deep ambivalence towards the sempiternity of monuments in the mountains was to resurface when the Great War raised the issue of memorialisation. The new strategies that were to emerge at the end of the Great War, in which 'Nature herself was to serve as a living memorial' (Mosse 1994, 87) indicate the deeply conflicted attitudes that the middle-class members of the F.R.C.C. had towards sites of memory, and their compelling desire not to relinquish 'milieu de mémoire, real environments of memory' (Nora 1989, 7).

\section{Death and the Great War 1914-18}

Each of the wartime issues of F.R.C.C Journal carried a 'Roll of Honour' for club members killed in the War. The Journal for 1916 is an example (various 1916, 63-76). It included an obituary for 'The Late Lehmann J. Oppenheimer' by Ashley P. Abraham. From an Anglo- 
German family in Manchester, Oppenheimer was the author of the classic account of pre-War Lakeland Climbing Heart of Lakeland. John Laycock provided an obituary for Siegfried Herford, scion of an old Manchester Unitarian family, of Anglo-German parentage and perhaps the best rock climber of the pre-War era (Oppenheimer 1988; Treacher 2000). Seven other names were also listed. (FRCCJ 1916, 72-7) The psychological toll on club members became increasingly unbearable. In the same edition of the journal, its editor, William T. Palmer of Kendal, wrote an apology for the delayed publication of the journal, reflecting on the fate of the nation and the sacrifices being made by club members:

'Yet, in this hour of gloom and pain, one cannot but think again and again of the Eternal Fells, of the great sympathies we have found there,- -and one looks forward even to the great day when, with Victory, the remnant shall meet again in the shadows of the mighty rocks.' (Palmer 1916, 77).

There W T Palmer's text ends but a new authorial voice interjects the final words of that issue of the journal, signed by Annie Palmer: 'At this point my husband has completely broken down.' The strain of 'his Recruiting Office duties' and 'the memories of brave climbers' causing him 'to lay aside his pen in tears'.

Palmers' longing for reunion found solace in the metaphors and aesthetics of the infinite (Nicolson 1959), 'the Eternal Fells', a victorious remnant returning to 'meet again in the shadows of the mighty rocks'. The passage is intended to convey a scarcely to be hopedfor topography of the afterlife as well as a post-War return to the hills. This psychological need for an imaginative re-peopling of cherished landscapes, linked to the idea that only nature endures, is apparent elsewhere in contemporary discourse and behaviour. George Mosse has reminded us that 'the War itself led to a heightened awareness of nature' which served to direct attention 'away from the impersonality of the war of modern technology and the trenches towards preindustrial ideals of individualism, chivalry, and the conquest of space and time'(Mosse 1994, 107). In her work on the Peak District, Melanie Tebbutt has drawn our attention to the imaginative linking by men on the Home Front of Pennine moorland landscapes to those on the Western Front, where enactive repertoires of strenuous rambling attempted to create a communion of shared endurance (Tebbutt 2004, 2006). Increasingly F.R.C.C. members expressed the need to link fallen comrades to the Lake District landscape, though the exact nature of a memorial was to prove a divisive issue. The 1917-18 issue of the F.R.C.C. Journal contained a letter from ten club members suggesting that the route Central Buttress on Scafell should be renamed after one of its first ascencionists, Siegfried Herford (Various 1917-8, 144). At the Buttermere club meet, New Year, 1919, a proposal was put forward which led to heated letters being published in the Manchester Guardian. An essay by the honorary editor, R. S. T. Chorley, , entitled 'The War Memorial' recounted the controversy:

'The suggestion which received favour was one contemplating the erection of shelters or 'dugouts' - as they were termed - at the foot of each of the principal crags’ (Chorley 1919, 229-31)

This provoked a lot of opposition on conservationist grounds, and debate in the Manchester Guardian. R. L. Charlton wrote on the 15 February 1919 that the proposal to 'improve' the 
traditional howffs at Scafell and Dow Crag, providing them with a concrete floor, corrugated iron roofs and memorial tablets, was the 'intrusion of the work of the plumber and the bricklayer upon those solitary places’ (Charlton 1919, 8). H. M. Kelly wrote in support of Charlton, noting that the F.R.C.C. did not represent the wishes of other clubs and suggesting that a memorial be erected in the churchyard at Wasdale. Noting that there was already one memorial cross to a climber who died far away from the mountains, as well as the Robinson cairn, Kelly continued: 'There is no telling where this carving and chipping will lead to as our mountains become more and more popular' (Kelly 1919, 5). The year 1919 also saw the F.R.C.C. involved in the campaign to stop the building of the Sty Head road from Borrowdale to Wasdale but even in the face of a major infrastructural threat to the symbolic 'Heart of Lakeland' protests were still made about personal memorials (Bicknell 1919, 4).

The proposed F.R.C.C. memorial was referred to the A.G.M. in November 1919. A number of other proposals had also been received. T. C. Ormiston-Chant had written a long article entitled 'War Memorial to Members Fallen in the War' which outlined a comprehensive plan for a series of 'Pocket Editions giving useful information for all parts of the Lake District'. He added the underlying reason for this was 'the very strong feeling against any Memorial to fallen Members taking the form of any structure that might mar the beauty of the District, and encroach on the rights of others than members of the Club' (Ormiston-Chant 1919, 257-61) ). Other suggestions received by the committee were the purchase of a building for a clubhouse in Coniston, a permanent club room at Wasdale and for the carving of members' names on a suitable crag, and, finally, 'the ambitious but in some ways alluring proposal that the Club should purchase a crag, and place it in the care of the National Trust - a memorial to last as long as the everlasting hills (Chorley 1919, 230).

\section{Figure 4 and 5 hereabouts, in colour on same page}

This last suggestion had come from H. P. Cain at the Coniston club meet in February, 1919(Anon 1923, 241). The decision had undoubtedly been delayed because in 1919 the club was asked by the 'Peace Celebration Beacons and Bonfires Committee to organise beacon flares on Scafell Pike' for Peace Day on the 19 July, the logistics of which absorbed much of their time (Scantlebury 1919, 14). In the Autumn of 1919 it was announced in the press that Lord Leconfield had created a memorial to the fallen of the Lake District by declaring commoners rights on all land over 3,000 ft on Scafell Pike, the symbolic summit of England, donating it to the National Trust. The idea had been at the instigation of Canon Rawnsley. A slate memorial was eventually erected on Scafell Pike, set into the summit cairn, with a dedication ceremony on 24 August 1921 (Rawnsley, Mrs 1921, 321-323). Similarly, in 1920 the Duke of Buccleugh donated Piel Castle and Island to the people of Barrow and District as a war memorial (War Memorials Archive, http://www.ukniwm.org.uk/server/show/conMemorial.4145). Matters seemed little advanced with the F.R.C.C. memorial at the A.G.M. of 8 November 1920. George Seatree, one of the elder statesmen of the club, complained in a letter of 24 November that whilst a memorial was an agenda item 'the subject was not reached in any form nor was any official statement forthcoming' (Seatree 1920, 213). Seatree's letter indicates that the committee had opened negotiations for the purchase of Great Gable. He objected to the potentially ruinous financial 
commitment. He urged caution lest it provoke landowners to restrict access and suggested a laissez faire approach until Access to Mountain's legislation was passed. His arguments typify the strategic, reflexive and self-regulatory tendencies frequently attributed to the liberal middle classes. Seatree tendered his own plan for a bronze memorial tablet with the names of the club's war dead (possibly also a list of those who served) at valley level in Wasdale:

'There is, we are well aware, a deep rooted feeling amongst climbers and mountain lovers, both homeland and Alpine, against erecting in the Valleys reminders of sad accidents which have occurred on neighbouring heights' (ibid, 213).

Despite this hostile intervention from one of the revered pioneers of Lakeland climbing, a small sub-committee was actively pursuing the land purchase option. They had attempted to purchase Pillar Rock from Lord Lonsdale (Anon 1923, 240-244) and subsequently to buy Napes Needle but negotiations around the sale of the Musgrave Estate fell through in 1920 (Anon1920, 8). Further attempts were made to acquire Row Head Farm in Wasdale, which included Great Gable. 'There seemed some prospect of success at one time, but the Trustees finally decided to offer the whole estate by auction in separate lots in March of 1923' (Anon 1923, 242). The club was out-bid at auction for the Row Head Farm estate. Not giving up, they approached the new owner, Mr. Herbert Walker, of Seascale, a former member of the F.R.C.C., asking to purchase all the land on the estate over 1,500 ft. The price eventually agreed was $£ 400$. The call went out on the 19 May 1923 to club members for donations. In October, 1923, the title-deeds of 3,000 acres of high mountain fellside were handed over to the National Trust (Palmer 1924, 365).

There were other examples of land purchase and donation to the National Trust in the Lake District in the immediate post-War years. Friars Crag, Lord's Island and Scarf Close Bay on Windermere were donated as a memorial to Canon Rawnsley in September 1922 (Anon 1922, 7). Outside of the Lake District, donations of any kind to the National Trust were infrequent in the north of England (Anon 1923a, 6). The War Memorials Archive records only seventeen instances of land donation as war memorials in Britain. Of those, three were in Lakeland counties (Scafell; Great Gable; Piel Island). Most of the rest were in the Home Counties (Grieves 2000). The Lakeland War-memorial land donations are by far the largest in terms of acreage and were also hugely symbolic. They contained the highest mountain summit in England and some of the most significant crags in the history of the development of rock climbing in Britain. The central high fells of the Lake District around Scafell Pike and overlooking Wasdale represented the very heart of a cherished and culturally valorised landscape.

Figures 6 and 7 hereabouts, in colour on same page please

Whilst the War had forced on everyone the realisation that 'remembrance is part of the landscape' (Winter 1995, 1), the F.R.C.C, with its deeply rooted conservationist tendencies remained reluctant to see artificial memorials in the hills. The club expressed the wish that 'the hills themselves will be left to speak for the dead' and 'the club desires no memorial raised with human hands be placed on their brows' determining only to put a 
'tablet in "some inconspicuous place"' (Anon 1923b, 9). The closest parallels to this idea of a sacralised landscape, in which nature was to serve as a living memorial to the fallen, was to be seen in the establishment of Heldenhaine in Germany and Austria, and the Jardin Funèbres in France, memorial groves 'the trees taking the place of rows of actual graves' (Mosse 1994, 87). In the Lake District, any form of artificiality or materiality that intruded on the landscape was rejected. In seeking to reconnect with milieux de mémoire the F.R.C.C. members asserted that, far from being part of the landscape, remembrance was the landscape; that landscape itself was the most powerful place of memory (Della Dora, 2008, 229). As such, the best memorial for the dead was to secure in perpetuity access to the land for the living, to renew the cycle of remembering and forgetting.

This attitude is clearly instanced in the dedicatory speeches for the bronze tablet war memorial on Great Gable, unveiled on 8 June 1924. A speech was made by the club president, Arthur Wakefield, a eulogy delivered by the poet and climbing doyen Geoffrey Winthrop Young, and prayers were said by the Rev. J. H. Smith. In 'In the account of the dedication ceremony the land is referred to as a 'National park'.... a full twenty-seven years before its eventual foundation. The bronze memorial tablet consisted of a relief map of the donation estate and a dedication, along with the names of the dead (Palmer 1924, 365)

(Figure 8). The bas-relief map of the land purchase is itself a symbolic appropriation of the landscape. A map is at once the distillation of Enlightenment rationality but also an inspiration, freeing the romantic imagination to construct imagined territories from the terrain that it surveyed. Aerial photography during the war had represented a new aspect of modernity with implications for the visual cultures of remembrance: 'Big hills were now flat shapes. There was no vanishing point, and no horizon' (Harris 2010, 25). The aesthetics of the infinite found in Modernism a visual topos that rejected the long recessional motifs of distance and perspective, substituting for it the omnispective abstraction of space seemingly without temporal distancing.

The speeches and the articles that describe them in the club journal leave no doubt that it was traditional liberal values that were being re-consecrated at the memorial ceremony. Geoffrey Winthrop Young chose to emphasise freedom, the perishability of all monuments and the enduring qualities of the landscape. Club members had given their lives for freedom:

'this rock stands, a witness, perishable also in the onset of time, that this realm of mountain earth is, in their honour, free. In token that their sacrifice bears witness still, beyond death, to the imperishable ideal of spiritual liberty, we commit to-day, not in bronze, but in unalterable faith, our thought of their triumph in the spirit to these spaces of power and light' (Palmer 1924, 366-7).

The anonymous author of the article 'The War Memorial' in the 1923 Journal chose to emphasise the conservationist message:

'If our friends died there is a corner of their own dear land which will for ever bear witness to the memory of them, and of the work they did- ' they have found an eternal monument among the everlasting hills' ... They gave their lives to save a heritage, and in their deaths they have secured that something of that heritage shall remain inviolate from vandalism' (Anon 1923, 240). 
Figure 9 and 10 hereabouts in colour please

This sacralisation of the Lake District landscape resolved a number of dissonances apparent in liberalism. Post-War sites of memory inevitably 'faced the past, not the future' (Winter 1995, 223) but by insisting that the land itself was a memorial, a space of 'power and light', the F.R.C.C. reasserted its belief that all hopes for an affective afterlife for club members should reside in memory and not in monuments. Instead of a funereal landscape, the club proposed a memorious landscape, 'a corner of their own dear land which will for ever bear witness to the memory' of the fallen. In communicating the past the F.R.C.C. sought to control the present, shaping the identity of place through a process of social mapping, instructing post-War generations in how to read a landscape (Barthel 1989). The experience of the War and the question of how to memorialise fallen comrades had thus fundamentally changed club members' attitudes to mass access. Maximising individual freedoms need not necessarily lead to a tragedy of the commons if post-War generations understood the very ground on which they walked was sacred, that there was a duty to remember. By removing the land from the marketplace in perpetuity, the metaphorical 'Eternal Hills' seemed perhaps attainable, the 'perfected liberal zone outside the city' a little closer to realisation (Anderson 2011, 94).

\section{Abbreviations}

FRCC - The Fell and Rock Climbing Club (of the English Lake District)

JFRCC - The Journal of the FRCC [facsimile copies available at

http://www.frcc.co.uk/frcc journals.asp]

\section{References}

Anderson, B. 2011. A liberal countryside? The Manchester Ramblers' Federation and the 'social readjustment' of urban climbers, in Urban History 38 (1), 84-102. [doi: http://dx.doi.org/10.1017/S0963926811000058]

Anderson, B. 2012. The construction of alpine landscape: building, representing and affecting the Eastern Alps, c. 1885-1914, in Journal of Cultural Geography 29 (2), 1-29. [doi:10.1080/08873631.2012.683288]

Anon 1908. The memorial to the late J. W. Robinson, in Journal of the Fell and Rock Climbing Club 1 (2), 126-31.

Anon 1909. A climber killed on Great Gable: The breaking of a rope, in The Manchester Guardian, 28 September, 1909, 4.

Anon 1920. Wasdale Hall estate withdrawn: only minor portions sold, in The Manchester Guardian, 1 October 1920, 8.

Anon 1922. New National Trust possessions: Friar's Crag to be dedicated on Thursday, in The Manchester Guardian 3 September 1922, 7.

Anon 1923. The War Memorial, in Journal of the Fell and Rock Climbing Club 6 (2), 240-4. Anon 1923a. The National Trust, in The Manchester Guardian 12 July, 1923, 6. 
Anon 1923b. Preserving the heart of Lakeland. 3,000-acre gift to the nation. Fell and Rock Climbing Club’s Great War memorial. Two famous tracts divided by Sty Head, The Manchester Guardian 15 October 1923, 9.

Argenti, N.1999. Ephemeral monuments, memory and royal sempiternity in a Grassfields kingdom, in The Art of Forgetting ed. A. Forty, and S. Küchler, Berg, 21-52.

Barthel, D. 1989. Historic preservation: A comparative analysis, in Sociological Forum 4 (1), 87-105.

Bicknell, R. 1919. The Styhead, in The Manchester Guardian,26 September 1919, 4.

Charlton, R. L. 1919. War memorials in the "Lakes”, in The Manchester Guardian,15 February 1919, 8.

Chorley, R. S. T. 1919. The war memorial, in Journal of the Fell and Rock Climbing Club 4 (3), 229-31.

Della Dora, V. 2008. Mountains and memory: embodied visions of ancient peaks in the nineteenth-century Aegean, in Transactions of the Institute of British Geographers NS 33, 217-32.

Fleming, F. 2000. Killing Dragons: The Conquest of the Alps, Granta.

Freeden, M. 1976. Biological and evolutionary roots of the New Liberalism in England, in Political Theory 4 (4), November, 471-90.

Freedgood, E. 2000. The uses of pain: cultural masochism and the colonisation of the future in Victorian mountaineering memoirs, in Victorian Writing About Risk: Imagining a Safe England in a Dangerous World, ed. E. Freedgood, Cambridge University Press, 99-131.

Grieves, K. 2000. Investigating local war memorial committees: demobilised soldiers, the bereaved and expressions of local pride in Sussex villages, 1918 - 1921, in The Local Historian 30 (1), 39-58.

Hall, B. K. 2004. Balfour, Francis Maitland (1851-1882), Oxford Dictionary of National Biography. Oxford University Press. [doi:10.1093/ref:odnb/1186] http://www.oxforddnb.com/view/article/1186 [accessed 11 Feb 2013]

Hankinson, A. 1988. A Century on the Crags: The Story of Rock Climbing in the Lake District, J. M. Dent.

Harrison, S. 2004. Forgetful and memorious landscapes, in Social Anthropology 12 (2), 13551.

Hoibian, O. 2000. Les Alpinistes en France: 1870-1950. Une Histoire Culturelle, L'Harmattan.

JFRCC Committee 1909. Committee Notes, in Journal of the Fell and Rock Climbing Club 1 (3) November 1909, 318-19.

Jones, O. G. 1900..Rock Climbing in the English Lake District, Abraham. (facsimile reprint, 1973, E. J. Morten).

Kelly, H.M. 1919. War memorials in the Lakes, in Manchester Guardian, 20 February 1919, 5.

Klein, K. 2011. A vertical world: the Eastern Alps and modern mountaineering, Journal of Historical Sociology 24 (4), December, 519-48, [doi:10.1111/j.1467-6443.2011.01417.x]

Kuchler, S. 1999. The place of memory, in The Art of Forgetting, ed. A. Forty and S. Küchler, Berg, 53-72. 
McCormack, D. P. 2010. Remotely sensing affective afterlives: the spectral geographies of material remains, in Annals of the Association of American Geographers 100 (3), 64054.

Mangan J. A. and Walvin, J. (eds.) 1987. Manliness and Morality: Middle-class Masculinity in Britain and America, 1800-1940, Manchester University Press.

Maslen-Jones, B. 2004. A Perilous Playground: Misadventure in Snowdonia and the Development of the Mountain Rescue Service 1805 to the 1990s, Bridge Books.

Mathieu, J.2006. The sacralisation of mountains in Europe during the modern age, in Mountain Research and Development 26 (4), 343-9.

Mosse, G. 1994. Fallen Soldiers: Reshaping the Memory of the World Wars, Oxford University Press.

Nicolson, M. H. 1959. Mountain Gloom and Mountain Glory: The Development of the Aesthetics of the Infinite. University of Washington Press.

Nora, P. 1989. Between memory and history: Les Lieux de Mémoire, in Representations 26: Special Issue, Memory and Counter-memory, 7-24.

Oppenheimer, L. J. 1988. Heart of Lakeland. The Ernest Press.

Ormiston-Chant, T. C. 1919. War memorial to members fallen in the war, in Journal of the Fell and Rock Climbing Club 4 (3), 257-61.

Palmer, W. T., 1924. Unveiling the war memorial tablet. Great Gable, June $8^{\text {th }} 1924$, in Journal of the Fell and Rock Climbing Club 6 (3), 365-8.

Palmer, W.T. and A. 1916. The Editor's Apology, in Journal of the Fell and Rock Climbing Club vol 4, No 1, November 1916, 77

Price, N. 1937. A Vagabond's Way: Haphazard Wanderings on the Fells. $3^{\text {rd }}$ edition. George Allen and Unwin Ltd.

Ranlett, J. 1983.“Checking nature’s desecration”: late Victorian environmental organisation, in Victorian Studies 26 (2), Winter, 197-222 http://www.jstor.org/stable/3827006 [Accessed 10 February 2013]

Rawnsley, Mrs 1921. War memorial on Scafell Pike. $24^{\text {th }}$ August 1921, in Journal of the Fell and Rock Climbing Club 5 (3), 321-3.

Scantlebury, E. H. P., 1919. Scafell Pike Peace Day, in Journal of the Fell and Rock Climbing Club 5 (1), 14-24.

Seatree, G. E., 1920. The Club’s war memorial, Journal of the Fell and Rock Climbing Club 5 (2), 213-16.

Taylor, H. 1997. A Claim on the Countryside: A History of the British Outdoor Movement. Keele University Press.

Tebbutt, M. 2004. Landscapes of loss: moorlands, manliness and the First World War, in Landscapes 5 (2), 114-27.

Tebbutt, M. 2006. Rambling and manly identity in Derbyshire’s Dark Peak, 1880s-1920s, in Historical Journal, 49 (4), 1125-53.

Treacher, K. 2000. Siegfried Herford: An Edwardian Rock Climber, The Ernest Press.

Waller, M. 2007. A Lakeland Pioneer: John Wilson Robinson of Whinfell Hall, Bookcase.

Various 1916. The Fell and Rock Club's Roll of Honour, in Journal of the Fell and Rock Climbing Club vol 4, No 1, November 1916, 64-76 
Various 1917-18. To the Editor of the Fell and Rock Climbing Club Journal, in Journal of the Fell and Rock Climbing Club 4 (2), 144.

Westaway , J. 2009. The German Community in Manchester, Middle-Class Culture and the Development of Mountaineering in Britain, c.1850-1914, in English Historical Review 124, 508 June, 571-604. [doi:10.1093/ehr/cep144]

Westaway, J. 2013. The origins and development of mountaineering and rock climbing tourism in the Lake District, c.1800-1914, in John K. Walton and Jason Woods (eds.), The Making of a Cultural Landscape: The English Lake District as Tourist Destination, 1750-2010, Ashgate.

Winter, J. 1995. Sites of Memory, Sites of Mourning: The Great War in European Cultural History, Cambridge University Press.

\section{Notes on contributor}

Jonathan Westaway is a Research Fellow in History in the University of Central Lancashire, Preston. His research interests examine the role of physical culture, education and technology, liberalism and modernity in shaping the outdoor movement, structuring masculinity and constructing approaches to landscapes in the late nineteenth century and early twentieth century. Contact: JWestaway@uclan.ac.uk 